\title{
Generoll Entomology \\ High diversity of bees detected in guarana crop and natural habitat due to the use of combined sampling methods

\author{
Cristiane Krug ${ }^{1 \oplus}$, Juliana Hipólito ${ }^{2,3 \bowtie \oplus}{ }^{\circ}$, Karine Schoeninger ${ }^{4 \oplus}$, Matheus Montefusco ${ }^{3 \oplus}$, Flávia Batista \\ Gomes $^{1 \oplus}$, Marcio Luiz de Oliveira ${ }^{3 \oplus} \&$ Thiago Mahlmann ${ }^{3 \odot}$
}

1. Embrapa Amazônia Ocidental, Manaus, AM. Brazil. 2. Universidade Federal da Bahia - UFBA, Salvador, BA, Brazil. 3. Instituto Nacional de Pesquisas da Amazônia - INPA, Manaus, AM, Brazil. 4. Instituto Biológico, Unidade de Referência em Controle Biológico, Campinas, SP, Brazil.

\section{EntomoBrasilis 14: e975 (2021)}

Edited by:

Alberto Moreira Silva-Neto

Article History:

Received: 21.x.2021

Accepted: $12 . x$ ii. 2021

Published: 27.xii.2021

Corresponding author:

Juliana Hipólito

७jhdsousa@yahoo.com

Funding agencies:

$\leftrightarrow$ Coordenação de Aperfeiçoamento de Pessoal de Nível Superior Brasil (CAPES); Conselho Nacional de Desenvolvimento Científico e Tecnológico (CNPq); Embrapa.

\begin{abstract}
Bees are the main pollinators of native and agricultural plants. Identifying and knowing these insects responsible for the environmental service of pollination is essential for the maintenance and management of pollination in agricultural systems, especially in a high diversity biome as the Amazon rainforest. Some crops in this region are dependent of benefited by wild pollinators, especially native plants like guarana. To address methodological aspects of monitoring bee diversity, samplings were carried out in an agricultural environment (guarana crop, Paullinia cupana) surrounded by Amazon natural habitat at Manaus, Amazonas State. We used three combined methods (two passive traps: Malaise and yellow pan-traps, and one active: hand nets) in different periods, with the same number of samplings (12 each). In total, 4,143 native bees belonging to 171 species were sampled; 117 species (1,926 individuals) were collected with Malaise trap, 15 (91 individuals) with pan-traps, and 114 (2,126 individuals) through active sampling. Only seven species were common to all methods, 60 species on two methods and 104 species were unique to one sampling method (50 with Malaise, two with pan-traps, and 52 with hand nets). We reinforce the need for complementary sampling to known bee diversity as the best strategy here was the joint use of active samples and Malaise traps. Recently the concern with Amazon preservation has aroused worldwide interest, a fact that shreds of evidence the need for studies of biodiversity and taxonomy in several areas, since very little is known of this vast region.
\end{abstract}

Keywords: Amazon; Apoidea; Malaise; diversity; hand-netting; pan-trap.

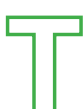
The Amazon basin includes the largest remaining area of tropical rainforest, been usually considered as one of the most important ecological systems on earth (Foley et al. 2007). Kress et al. (1998) stated that one of the major challenges for environmental conservation in the next century would be the preservation of habitats rich in species as the Amazon basin. More than twenty years after their publication, we are facing biodiversity loss (ELLWANGER et al. 2020), at the entire planet (CORLETT et al. 2020; RONDEAU et al. 2020). Impacts for this biodiversity loss comprises threats to our way of life that includes food security through biodiversity loss. In this sense, we know that pollination is one of the key environmental services for the environment and for sustainable agriculture, as about $75 \%$ of cultivated plants rely on cross-pollination for fruit and seed production (KLeIN et al. 2007). The main group of pollinators is the bees, due to their dependence on floral resources such as pollen and nectar.

According to the Discover Life Bee Species Guide and World Checklist (Ascher \& Pickering 2018) about 20,350 bee species are recognized in the world, of these the Taxonomic Catalog of the Brazilian Fauna (CTFB) recognizes at least 1,781 for Brazil (Oliveira 2015). However, it is believed that less than half of the diversity of bees in the Neotropical region has been described. Pinheiro-Machado et al. (2002) published a state of knowledge of Brazilian bee surveys, pointing out that not a single bee community survey has ever been conducted in the Amazon region until 20 years ago. According to them, studies on local bee diversity in this ecosystem are from early collections made by DUCKE (1906), and other studies on specific groups such as Centris (Morato et al. 1999) Euglossini (Oliveira \& Campos 1995; Oliveira 1999) and Meliponini (Camargo 1970; OliveIRA et al. 1995). More recently, several articles have drawn attention to the rich biodiversity of pollinators of Amazonian crops, such as Brazilian nuts (Bertholletia excelsa) (e.g., MAuÉs et al. 2015, 2018), guarana (Paullinia cupan) (e.g., Krug et al. 2015; Krug et al. 2018; Oliveira et al. 2020), açaí (Euterpe spp.) (e.g., Campiell et al. 2018; BezerRa et al. 2020), and in protected areas as in the Carajás Reserve (e.g., BorgEs et al. 2020; GIANNINI et al. 2020) in Pará State.

In faunistic surveys and pollination studies, bees are usually captured while collecting food on flowers (SILVEIRA et al. 2002). However, in several Amazon Forest spots, this is practically impossible due to the scarcity of flowering plants in the understory or even the difficulty to walk through vegetation (due to high plant density). One alternative is the use of flight interception traps, such as Malaise, that always collect bees, some of which are very rare in the collections, such as parasitic bees and species restricted to forest environments (Silveira et al. 2002). Alternatively, sampling on flowers that occur at forest border, near crop areas, whenever possible, could be a good strategy, since naturally, this field will exert a great deal of appeal to local species. Therefore, the use of alternative sampling methods to study biodiversity 
in places not yet surveyed and with little access or even in places already surveyed but by only one method can be an important choice to evaluate the bee community.

Guarana is an important and traditional Amazon crop that is exclusively grown in Brazil, with great economic and social importance, especially in the Amazon region, where it is cultivated by large and small producers (TAVAREs et al. 2005). Guarana is widely visited by insects, especially bees, the main pollinators (SChultz \& VAloIs 1974; Escobar et al. 1984; KRUG et al. 2015). Thus, this crop can be an excellent model to be sampled by different sampling methods to study its pollinator fauna. Here we evaluated the influence of different sampling methods on recording native bee diversity in an guarana crop area.

\section{MATERIAL AND METHODS}

Study area. We sampled the local community of native bees in an experimental guarana crop field and surrounding area at Embrapa Amazônia Ocidental. The crop field area had approximately 10 hectares and was located at $\mathrm{km} 29$ of the AM 010 highway ( $\left.2^{\circ} 53^{\prime} 29.19^{\prime \prime} \mathrm{S} / 5^{\circ} 58^{\prime} 40.58^{\prime \prime} \mathrm{W}\right)$, in Manaus, Amazonas State, Brazil (Figure 1). The immediate surroundings of the guarana plantation were composed of diverse ruderal plants; these plants also grew inside the crop, between the rows. The plantation was distant from the native vegetation about 30-50 meters, being characterized as native vegetation in an advanced stage of regeneration. The clime in the region is tropical humid, type AM, with an average annual temperature of $26.5^{\circ} \mathrm{C}$ (KÖPPEN 1936). According to monthly historical series of 40 years of precipitation evaluated by ANTONIO (2017) the rainy season generally occurs between the months of January and June, when $65 \%$ of the total annual precipitation in the region occurs, with a monthly average of $279.05 \mathrm{~mm}$ in these months. The same authors also cite a notable reduction in rainfall between July and September, with a monthly average rainfall of $159.15 \mathrm{~mm}$ between July and December.

We used three methods of sampling, two passive and one active methodology, in different periods, however with the same number of samples (twelve) each, described below. As previously works with this crop indicates that native bees are the main pollinators (Schultz \& VAloIs 1974; Escobar et al. 1984; KRUG et al. 2015), we focused only on those bees and thus did not record the exotic bee, Apis mellifera Linnaeus on our samplings.

Passive samplings. Malaise type TOWNEs (1972) and yellow pan-traps (Möerick type) (Figure 2A-B), were arranged in two distinct sampling lines, each one with three sampling points (see Figure 1B, in Schoeninger et al. 2019). The first sampling point was established outside the crop, more precisely within 50 meters inside the adjacent native vegetation, the second point at the edge of the crop, and the third within the crop. The distance between each collection point was $60 \mathrm{~m}$. At each sampling point, a Malaise trap and four pan-traps were set up, which were arranged around Malaise at a distance of five meters, in a total of six Malaise traps and 24 pan-traps per collection point (SCHOENINGER et al. 2019).

Samples were taken every two weeks between September 2012 and February 2013, totaling 12 samplings. Each sampling remained in the field for four days before the samples were collected. The sampling period covered the flowering period of guarana, as well as the transition and beginning of the rainy season and less rainy season.

Malaise traps allows the capture of insects through flight

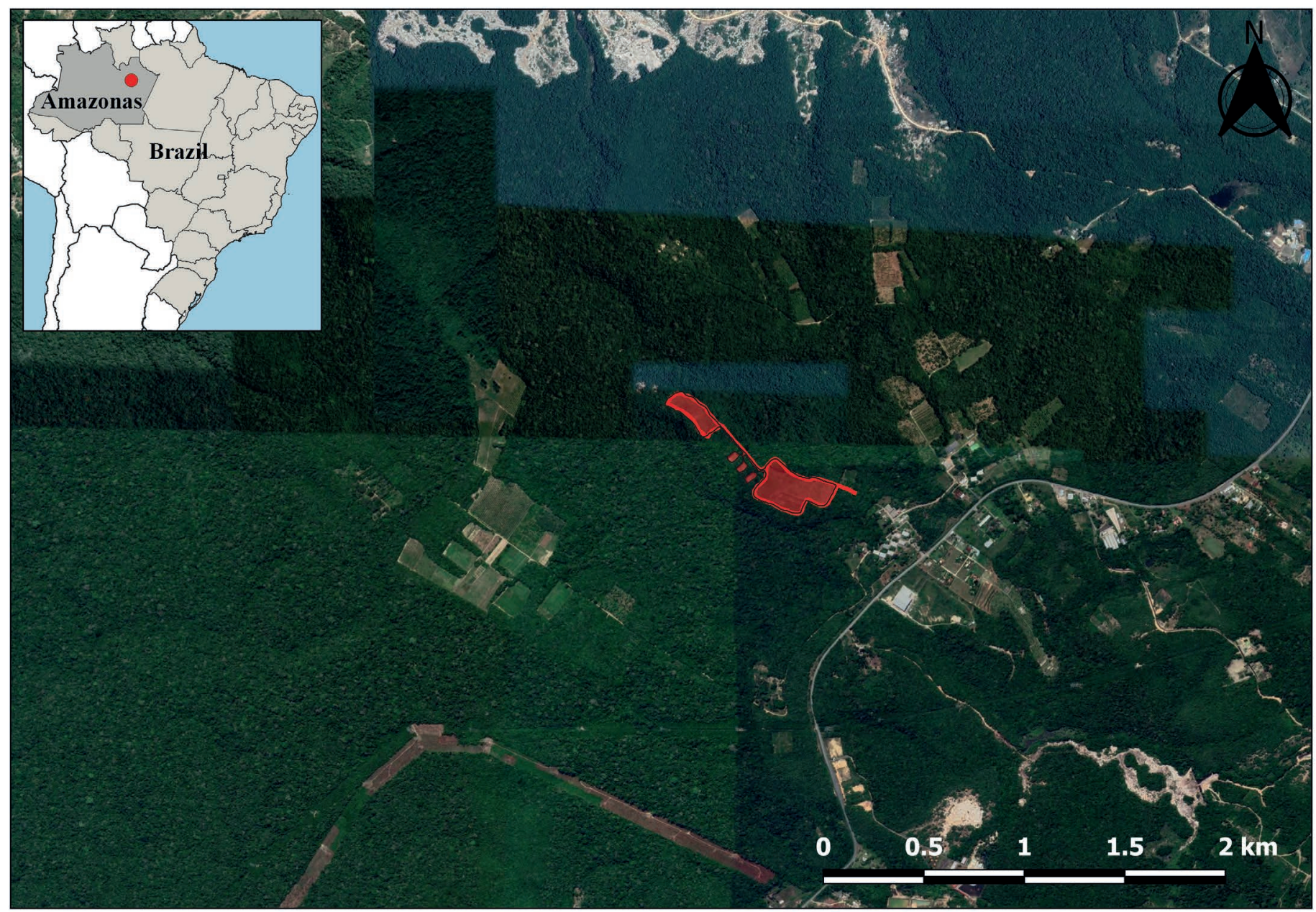

Figure 1. Location of the experimental area of guarana plantation (in red) (scientific name) at Embrapa Amazônia Ocidental and bee samplings site in Manaus/AM. 
interception, besides being a permanent technique, works independently of attractiveness to obtain satisfactory results (LEWIS \& WHITFIELD 1999). Pan-traps (original white plastic trays) had the interior painted with yellow spray, once this attract insects as a function of the color, they measured $20 \mathrm{~cm} \mathrm{x}$ $10 \mathrm{~cm} \times 5 \mathrm{~cm}$ and were disposed on the ground, containing a solution of water and detergent, which traps the insects inside the solution.

Active samplings. Active samplings were carried out by two experienced collectors with entomological nets (Figure 2C), walking side by side. In the studied area, a collection transect of approximately 3.5 kilometers long was defined into the forest and in the edge, as well as into the guarana crop field. Throughout the transect, all flowering herbaceousshrub plants were observed in search of floral visiting bees. Samplings were carried out monthly (2 days/month), always in the same transect performed completed each day, between June/2016 and May/2017, on two consecutive days, on the first day from 11 to $17 \mathrm{~h}$ and the second day from 5 to $11 \mathrm{~h}$, totaling 12 hours of monthly collections. We use entomological nets up to 3 meters in length to reach flowers at different heights.

Identification and data analysis. All the captured bees were properly prepared and labeled before identification. The identification was carried out through specialized bibliographic material and comparison with species identified in the Invertebrate Collection of the National Institute of Amazonian Research (INPA). All individuals were identified to the lowest possible level and deposited at INPA Collection.

The diversity index of Shannon-Wiener $\left(\mathrm{H}^{\prime}\right)$ was used to quantitatively estimate diversity in the community by assigning greater weight to the rare species was calculated using the PASt program (Paleontological Statistics 1.32, HAMmER et al. 2001). We also estimate the species accumulation curves (or collector's curves) for each sampling method through the 'BAT' package in R software (R CORE TEAM 2019), using 1000 random permutations to the sampling order with the function alpha.accum (this function estimate the alpha diversity of a single site with accumulation of sampling units by returning a matrix of sampling units $x$ diversity values) (CARDoso et al. 2015).

\section{RESULTS}

The combined results of all three methods revealed 171 native bee species in an agricultural environment (guarana crop) and close to the crop field, at the forest border. The 4,143 specimens of bees sampled belong to 55 genera and the five families present in Brazil (Table 1 and 2). Active samplings were responsible for $51 \%$ and $66 \%$ of the collected bee specimens and species, respectively, and malaise trap samplings were responsible for $46 \%$ and $68 \%$ of the collected bee specimens and species, and pan-traps were only responsible for $2 \%$ and $9 \%$, respectively.

Only seven species were common to all methods, 60 species on two methods and 104 species were unique to one sampling method (50 to Malaise traps, 02 to pan-traps, and 52 active samples) (Table 3 ). The diversity index $\mathrm{H}^{\prime}$ for the whole area was 3.83 while active samples (3.59) and Malaise trap (3.42), obtained similar results and, pan-traps (1.90), the lowest diversity index.

Species accumulation curves also evidenced the difference among methods (Figure 3). Active and malaise samplings seem to approach an asymptote while the pan-traps were not as effective in reflecting local biodiversity.

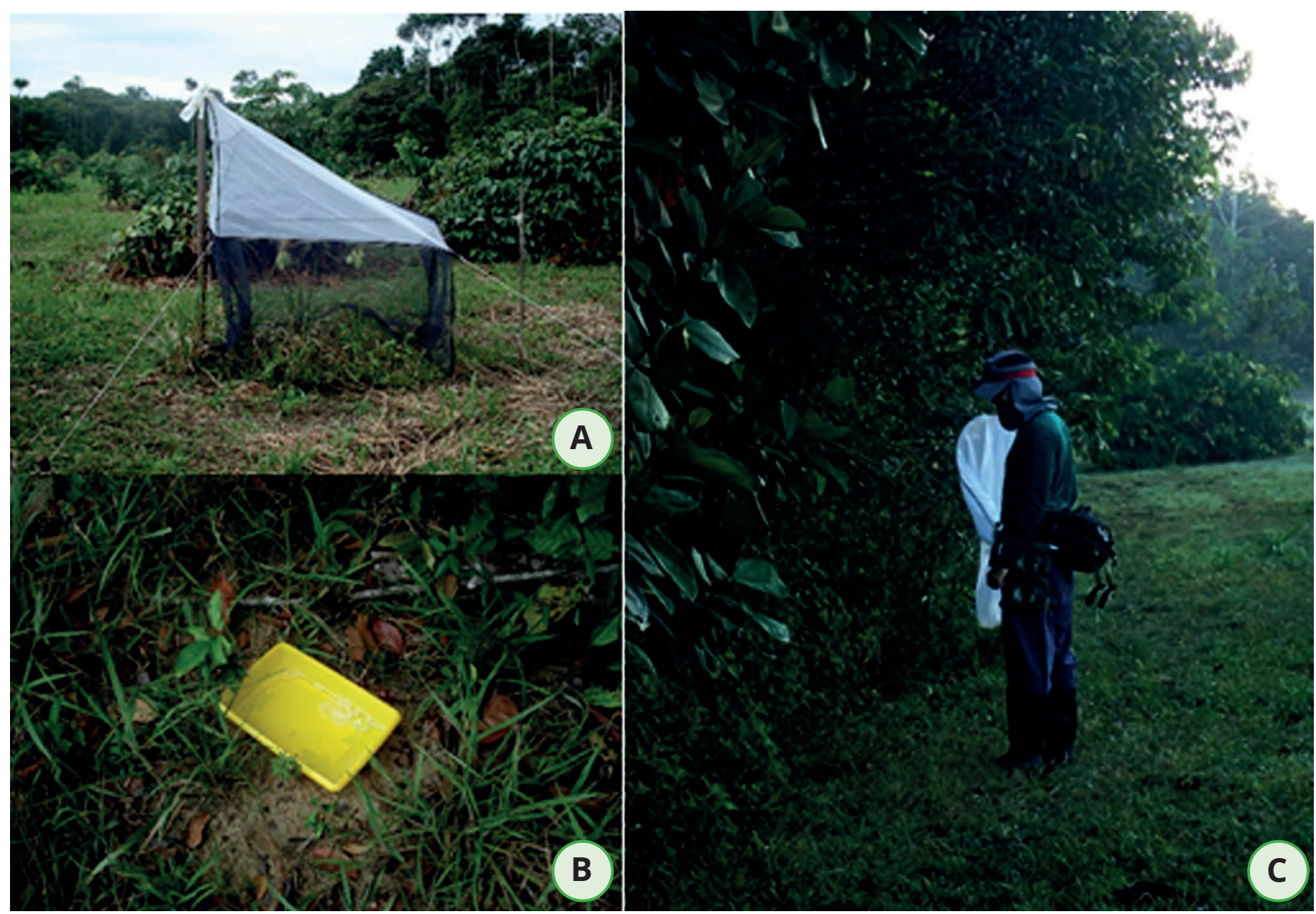

Figure 2. Sampling methods used to collect bees on the guarana crop (scientific name): A- active sampling with entomological nets; B - the passive trap of Malaise type Townes; C - yellow pan-traps (Möerick type). 
Table 1. Summary of bee sampling efforts in one guarana crop (scientific name) field and surrounding natural habitat in Brazilian Amazon.

\begin{tabular}{|c|c|c|c|c|c|}
\hline \multirow{2}{*}{ Bee sampling } & \multirow{2}{*}{ Number of collected } & \multirow{2}{*}{ Total } & \multicolumn{3}{|c|}{ Methodology } \\
\hline & & & Malaise & Pan-traps & Active \\
\hline \multirow{2}{*}{ Total } & specimens & 4,143 & 1,926 & 91 & 2,126 \\
\hline & species & 171 & 117 & 15 & 114 \\
\hline \multirow{2}{*}{ Andrenidae } & specimens & 1 & 1 & 0 & 0 \\
\hline & species & 1 & 1 & 0 & 0 \\
\hline \multirow{2}{*}{ Apidae } & specimens & 3,341 & 1,380 & 34 & 1,927 \\
\hline & species & 115 & 73 & 9 & 88 \\
\hline \multirow{2}{*}{ Colletidae } & specimens & 34 & 3 & 0 & 31 \\
\hline & species & 5 & 2 & 0 & 3 \\
\hline \multirow{2}{*}{ Halictidae } & specimens & 731 & 522 & 57 & 152 \\
\hline & species & 38 & 35 & 6 & 16 \\
\hline \multirow{2}{*}{ Megachilidae } & specimens & 36 & 20 & 0 & 16 \\
\hline & species & 12 & 6 & 0 & 7 \\
\hline
\end{tabular}

*Apis mellifera scutellata Lepeletier was not included in the analyzes.

Table 2. Bee species and the number of specimens sampled by method (M, Malaise; P, pan-traps; A, Active) in one guarana crop field (scientific name) and surrounding natural habitat in the Brazilian Amazon.

\begin{tabular}{|c|c|c|c|c|c|c|}
\hline $\mathbf{N}^{\circ}$ & Family & Species & M & $\mathbf{P}$ & A & Total \\
\hline \multicolumn{7}{|c|}{ Andrenidae } \\
\hline 1 & & Oxaea flavescens Klug & 1 & 0 & 0 & 1 \\
\hline \multicolumn{7}{|c|}{ Apidae } \\
\hline 2 & & Ancyloscelis apiformis (Fabricius) & 0 & 2 & 0 & 2 \\
\hline 3 & & Aparatrigona impunctata (Ducke) & 380 & 0 & 114 & 494 \\
\hline 4 & & Camargoia camargoi Moure & 4 & 0 & 0 & 4 \\
\hline 5 & & Centris (Centris) flavifrons (Fabricius) & 1 & 0 & 0 & 1 \\
\hline 6 & & Centris (Centris) nitens Lepeletier & 0 & 0 & 1 & 1 \\
\hline 7 & & Centris (Centris) varia (Erichson) & 1 & 0 & 0 & 1 \\
\hline 8 & & Cephalotrigona femorata (Smith) & 0 & 0 & 5 & 5 \\
\hline 9 & & Cephalotrigona sp.1 & 0 & 0 & 1 & 1 \\
\hline 10 & & Ceratina (Calloceratina) sp.n. Mahlmann (in prep.) & 4 & 0 & 0 & 4 \\
\hline 11 & & Ceratina (Ceratinula) sp.1 & 0 & 0 & 1 & 1 \\
\hline 12 & & Ceratina (Ceratinula) sp.2 & 0 & 0 & 9 & 9 \\
\hline 13 & & Ceratina (Crewella) sp.1 & 12 & 0 & 45 & 57 \\
\hline 14 & & Ceratina (Crewella) sp.10 & 0 & 0 & 1 & 1 \\
\hline 15 & & Ceratina (Crewella) sp.11 & 0 & 0 & 1 & 1 \\
\hline 16 & & Ceratina (Crewella) sp.2 & 3 & 0 & 0 & 3 \\
\hline 17 & & Ceratina (Crewella) sp.4 & 8 & 0 & 5 & 13 \\
\hline 18 & & Ceratina (Crewella) sp.5 & 6 & 0 & 0 & 6 \\
\hline 19 & & Ceratina (Crewella) sp. 6 & 6 & 0 & 0 & 6 \\
\hline 20 & & Ceratina (Crewella) sp.7 & 2 & 0 & 10 & 12 \\
\hline 21 & & Ceratina (Neoclavicera) rotundiceps Smith & 1 & 0 & 0 & 1 \\
\hline 22 & & Epicharis (Hoplepicharis) aff. fasciata Lepeletier \& Serville & 0 & 0 & 1 & 1 \\
\hline 23 & & Euglossa (Glossura) ignita Smith & 0 & 0 & 1 & 1 \\
\hline 24 & & Euglossa (Glossura) sp.1 & 4 & 0 & 1 & 5 \\
\hline 25 & & Euglossa (Glossura) sp.2 & 1 & 0 & 0 & 1 \\
\hline 26 & & Euglossa (Glossuropoda) intersecta Latreille & 0 & 0 & 1 & 1 \\
\hline 27 & & Euglossa sp.1 & 0 & 0 & 2 & 2 \\
\hline 28 & & Eulaema (Apeulaema) mocsaryi (Friese) & 1 & 0 & 0 & 1 \\
\hline 29 & & Eulaema (Eulaema) meriana (Olivier) & 0 & 0 & 1 & 1 \\
\hline 30 & & Exaerete frontalis (Guérin) & 0 & 0 & 3 & 3 \\
\hline 31 & & Exaerete smaragdina (Guérin) & 0 & 0 & 4 & 4 \\
\hline
\end{tabular}


Table 2. Continue...

\begin{tabular}{|c|c|c|c|c|c|c|}
\hline $\mathbf{N}^{\circ}$ & Family & Species & M & $\mathbf{P}$ & A & Total \\
\hline 32 & & Exomalopsis (Exomalopsis) analis Spinola & 0 & 0 & 1 & 1 \\
\hline 33 & & Exomalopsis (Exomalopsis) auropilosa Spinola & 159 & 17 & 48 & 224 \\
\hline 34 & & Exomalopsis (Exomalopsis) minor Schrottky & 97 & 9 & 31 & 137 \\
\hline 35 & & Exomalopsis sp.1 & 3 & 0 & 1 & 4 \\
\hline 36 & & Exomalopsis sp.2 & 0 & 0 & 1 & 1 \\
\hline 37 & & Florilegus (Euflorilegus) festivus (Smith) & 1 & 0 & 1 & 2 \\
\hline 38 & & Frieseomelitta paranigra (Schwarz) & 1 & 1 & 0 & 2 \\
\hline 39 & & Frieseomelitta portoi (Friese) & 1 & 0 & 2 & 3 \\
\hline 40 & & Frieseomelitta sp.1 & 0 & 0 & 2 & 2 \\
\hline 41 & & Frieseomelitta sp.n. F.F. de Oliveira (in prep.) & 0 & 0 & 62 & 62 \\
\hline 42 & & Frieseomelitta trichocerata Moure & 0 & 0 & 52 & 52 \\
\hline 43 & & Geotrigona subnigra (Schwarz) & 0 & 0 & 18 & 18 \\
\hline 44 & & Lestrimelitta aff. glabrata Camargo \& Moure & 6 & 0 & 0 & 6 \\
\hline 45 & & Lestrimelitta glaberrima Oliveira \& Marchi & 3 & 0 & 0 & 3 \\
\hline 46 & & Lestrimelitta limao (Smith) & 2 & 0 & 0 & 2 \\
\hline 47 & & Lestrimelitta sp.1 & 1 & 0 & 0 & 1 \\
\hline 48 & & Leurotrigona pusilla Moure \& Camargo & 10 & 0 & 3 & 13 \\
\hline 49 & & Melipona (Eomelipona) amazonica Schulz & 8 & 0 & 3 & 11 \\
\hline 50 & & Melipona (Eomelipona) bradleyi Schwarz & 2 & 0 & 0 & 2 \\
\hline 51 & & Melipona (Eomelipona) illustris Schwarz & 2 & 0 & 0 & 2 \\
\hline 52 & & Melipona (Eomelipona) puncticollis Friese & 3 & 0 & 5 & 8 \\
\hline 53 & & Melipona (Michmelia) captiosa Moure & 1 & 0 & 1 & 2 \\
\hline 54 & & Melipona (Michmelia) fulva Lepeletier & 26 & 0 & 59 & 85 \\
\hline 55 & & Melipona (Michmelia) seminigra merrillae Cockerell & 0 & 0 & 22 & 22 \\
\hline 56 & & Melipona (Michmelia) seminigra seminigra Friese & 0 & 0 & 5 & 5 \\
\hline 57 & & Mesoplia rufipes (Perty) & 1 & 1 & 0 & 2 \\
\hline 58 & & Mesoplia sp.1 & 0 & 0 & 1 & 1 \\
\hline 59 & & Nannotrigona melanocera (Schwarz) & 11 & 0 & 90 & 101 \\
\hline 60 & & Nannotrigona schultzei (Friese) & 5 & 0 & 11 & 16 \\
\hline 61 & & Nogueirapis minor (Moure \& Camargo) & 0 & 0 & 2 & 2 \\
\hline 62 & & Nomada sp.1 & 8 & 0 & 5 & 13 \\
\hline 63 & & Nomada sp.2 & 17 & 0 & 0 & 17 \\
\hline 64 & & Osiris sp.1 & 0 & 0 & 1 & 1 \\
\hline 65 & & Osiris sp.2 & 0 & 0 & 5 & 5 \\
\hline 66 & & Oxytrigona obscura (Friese) & 3 & 0 & 0 & 3 \\
\hline 67 & & Paratetrapedia basilaris Aguiar \& Melo & 1 & 0 & 36 & 37 \\
\hline 68 & & Paratetrapedia connexa (Vachal) & 0 & 0 & 8 & 8 \\
\hline 69 & & Paratetrapedia sp.1 & 4 & 0 & 7 & 11 \\
\hline 70 & & Paratetrapedia sp.2 & 4 & 0 & 0 & 4 \\
\hline 71 & & Paratetrapedia sp.3 & 3 & 0 & 70 & 73 \\
\hline 72 & & Paratetrapedia sp.4 & 0 & 0 & 38 & 38 \\
\hline 73 & & Paratetrapedia sp.5 & 0 & 0 & 1 & 1 \\
\hline 74 & & Paratrigona euxanthospila Camargo \& Moure & 5 & 0 & 4 & 9 \\
\hline 75 & & Paratrigona melanaspis Camargo \& Moure & 17 & 0 & 11 & 28 \\
\hline 76 & & Paratrigona pannosa Moure & 14 & 0 & 34 & 48 \\
\hline 77 & & Paratrigona sp.1 & 0 & 1 & 1 & 2 \\
\hline 78 & & Partamona auripennis Pedro \& Camargo & 0 & 0 & 12 & 12 \\
\hline 79 & & Partamona mourei Camargo & 14 & 0 & 3 & 17 \\
\hline 80 & & Partamona pearsoni (Schwarz) & 6 & 0 & 0 & 6 \\
\hline 81 & & Partamona vicina Camargo & 26 & 0 & 18 & 44 \\
\hline 82 & & Plebeia alvarengai Moure & 10 & 0 & 3 & 13 \\
\hline
\end{tabular}


Table 2. Continue...

\begin{tabular}{|c|c|c|c|c|c|c|}
\hline $\mathbf{N}^{\circ}$ & Family & Species & M & $\mathbf{P}$ & A & Total \\
\hline 83 & & Plebeia minima (Gribodo) & 45 & 0 & 1 & 46 \\
\hline 84 & & Plebeia sp.1 & 36 & 1 & 0 & 37 \\
\hline 85 & & Ptilotrigona lurida (Smith) & 2 & 0 & 348 & 350 \\
\hline 86 & & Scaptotrigona bipunctata (Lepeletier) & 5 & 0 & 4 & 9 \\
\hline 87 & & Scaptotrigona sp.n. Oliveira (in prep.) & 34 & 0 & 1 & 35 \\
\hline 88 & & Scaura amazonica Nogueira, Oliveira \& Oliveira & 8 & 0 & 43 & 51 \\
\hline 88 & & Scaura latitarsis (Friese) & 1 & 0 & 4 & 5 \\
\hline 89 & & Scaura longula (Lepeletier) & 7 & 0 & 1 & 8 \\
\hline 91 & & Tetragona dorsalis (Smith) & 18 & 0 & 9 & 27 \\
\hline 92 & & Tetragona handlirschii (Friese) & 3 & 0 & 16 & 19 \\
\hline 93 & & Tetragona kaieteurensis (Schwarz) & 0 & 0 & 14 & 14 \\
\hline 94 & & Tetragona essequiboensis (Schwarz) & 1 & 0 & 1 & 2 \\
\hline 95 & & Tetragona goettei (Friese) & 16 & 0 & 13 & 29 \\
\hline 96 & & Tetragona kaieteurensis (Schwarz) & 21 & 0 & 11 & 32 \\
\hline 97 & & Tetragonisca angustula (Latreille) & 55 & 0 & 53 & 108 \\
\hline 98 & & Tetrapedia sp.1 & 0 & 0 & 1 & 1 \\
\hline 99 & & Trigona branneri Cockerell & 5 & 0 & 79 & 84 \\
\hline 100 & & Trigona cilipes (Fabricius) & 5 & 0 & 77 & 82 \\
\hline 101 & & Trigona gr. fuscipennis & 6 & 0 & 34 & 40 \\
\hline 102 & & Trigona guianae Cockerell & 169 & 1 & 203 & 373 \\
\hline 103 & & Trigona hypogea Silvestri & 0 & 0 & 76 & 76 \\
\hline 104 & & Trigona williana Friese & 9 & 0 & 21 & 30 \\
\hline 105 & & Trigonisca cf. dobzhanskyi (Moure) & 0 & 0 & 1 & 1 \\
\hline 106 & & Trigonisca cf. vitrifrons Albuquerque \& Camargo & 17 & 1 & 1 & 19 \\
\hline 107 & & Trigonisca sp.1 & 2 & 0 & 0 & 2 \\
\hline 108 & & Trigonisca sp.2 & 1 & 0 & 0 & 1 \\
\hline 109 & & Tropidopedia duckeana Aguiar \& Melo & 0 & 0 & 4 & 4 \\
\hline 110 & & Tropidopedia eliasi Aguiar \& Melo & 0 & 0 & 11 & 11 \\
\hline 111 & & Tropidopedia gr. pallidipennis & 0 & 0 & 1 & 1 \\
\hline 112 & & Tropidopedia guaranae Mahlmann \& Oliveira & 3 & 0 & 0 & 3 \\
\hline 113 & & Xylocopa (Neoxylocopa) aurulenta (Fabricius) & 2 & 0 & 2 & 4 \\
\hline 114 & & Xylocopa (Neoxylocopa) frontalis (Olivier) & 0 & 0 & 1 & 1 \\
\hline 115 & & Xylocopa (Neoxylocopa) tegulata Friese & 0 & 0 & 10 & 10 \\
\hline 116 & & Xylocopa (Schonnherria) sp.1 & 0 & 0 & 1 & 1 \\
\hline \multicolumn{7}{|c|}{ Colletidae } \\
\hline 117 & & Colletes sp.1 & 2 & 0 & 0 & 2 \\
\hline 118 & & Hylaeus (Gongyloprosopis) orbicus (Vachal)* & 0 & 0 & 12 & 12 \\
\hline 119 & & Hylaeus (Hylaeopsis) sp.1 & 1 & 0 & 0 & 1 \\
\hline 120 & & Hylaeus sp.1 & 0 & 0 & 18 & 18 \\
\hline 121 & & Ptiloglossa sp.1 & 0 & 0 & 1 & 1 \\
\hline \multicolumn{7}{|c|}{ Halictidae } \\
\hline 122 & & Augochlora sp.1 & 15 & 0 & 53 & 68 \\
\hline 123 & & Augochlora sp.10 & 1 & 0 & 0 & 1 \\
\hline 124 & & Augochlora sp.2 & 8 & 0 & 7 & 15 \\
\hline 125 & & Augochlora sp.3 & 4 & 0 & 7 & 11 \\
\hline 126 & & Augochlora sp.4 & 4 & 0 & 3 & 7 \\
\hline 127 & & Augochlora sp.5 & 112 & 1 & 0 & 113 \\
\hline 128 & & Augochlora sp.6 & 3 & 0 & 0 & 3 \\
\hline 129 & & Augochlora sp.7 & 1 & 0 & 0 & 1 \\
\hline 130 & & Augochlora sp.8 & 1 & 0 & 0 & 1 \\
\hline
\end{tabular}


Table 2. Continue...

\begin{tabular}{|c|c|c|c|c|c|c|}
\hline $\mathbf{N}^{\circ}$ & Family & Species & M & $\mathbf{P}$ & A & Total \\
\hline 131 & & Augochlora sp.9 & 4 & 0 & 0 & 4 \\
\hline 132 & & Augochloropsis cupreola (Cockerell) & 81 & 4 & 31 & 116 \\
\hline 133 & & Augochloropsis hebescens (Smith) & 0 & 0 & 7 & 7 \\
\hline 134 & & Augochloropsis sp.1 & 4 & 0 & 1 & 5 \\
\hline 135 & & Augochloropsis sp.2 & 21 & 0 & 0 & 21 \\
\hline 136 & & Augochloropsis sp.3 & 11 & 0 & 1 & 12 \\
\hline 137 & & Augochloropsis sp.4 & 91 & 0 & 11 & 102 \\
\hline 138 & & Augochloropsis sp.5 & 1 & 0 & 0 & 1 \\
\hline 139 & & Augochloropsis sp.6 & 5 & 0 & 0 & 5 \\
\hline 140 & & Augochloropsis sp.7 & 2 & 0 & 0 & 2 \\
\hline 141 & & Habralictus sp.1 & 2 & 0 & 0 & 2 \\
\hline 142 & & Lasioglossum (Dialictus) sp.1 & 80 & 34 & 13 & 127 \\
\hline 143 & & Lasioglossum (Dialictus) sp.2 & 2 & 2 & 0 & 4 \\
\hline 144 & & Lasioglossum (Dialictus) sp.3 & 2 & 0 & 1 & 3 \\
\hline 145 & & Lasioglossum (Dialictus) sp.4 & 1 & 0 & 0 & 1 \\
\hline 146 & & Megalopta amoena (Spinola) & 1 & 0 & 5 & 6 \\
\hline 147 & & Megalopta genalis Meade-Waldo & 2 & 0 & 0 & 2 \\
\hline 148 & & Megalopta mura Santos \& Melo & 1 & 0 & 0 & 1 \\
\hline 149 & & Megalopta sodalis (Vachal) & 0 & 0 & 7 & 7 \\
\hline 150 & & Megaloptidia nocturna (Friese) & 1 & 0 & 2 & 3 \\
\hline 151 & & Neocorynura sp.1 & 2 & 0 & 0 & 2 \\
\hline 152 & & Neocorynura sp.2 & 1 & 0 & 0 & 1 \\
\hline 153 & & Neocorynura sp.3 & 1 & 0 & 0 & 1 \\
\hline 154 & & Pereirapis cf. semiaurata (Spinola) & 3 & 15 & 2 & 20 \\
\hline 155 & & Pereirapis sp.2 & 0 & 1 & 0 & 1 \\
\hline 156 & & Pseudaugochlora flammula Almeida & 1 & 0 & 0 & 1 \\
\hline 157 & & Pseudaugochlora graminea (Fabricius) & 47 & 0 & 1 & 48 \\
\hline 158 & & Stilbochlora aff. eickworti (Engel, Brooks \& Yanega) & 3 & 0 & 0 & 3 \\
\hline 159 & & Temnosoma sp.1 & 3 & 0 & 0 & 3 \\
\hline \multicolumn{7}{|c|}{ Megachilidae } \\
\hline 160 & & Anthodioctes cf. santosi Urban & 0 & 0 & 1 & 1 \\
\hline 161 & & Anthodioctes sp.1 & 1 & 0 & 0 & 1 \\
\hline 162 & & Coelioxys sp.1 & 0 & 0 & 1 & 1 \\
\hline 163 & & Megachile (Pseudocentron) curvipes Smith & 0 & 0 & 2 & 2 \\
\hline 164 & & Megachile sp.1 & 14 & 0 & 0 & 14 \\
\hline 165 & & Megachile sp.2 & 1 & 0 & 7 & 8 \\
\hline 166 & & Megachile sp.3 & 2 & 0 & 0 & 2 \\
\hline 167 & & Megachile sp.4 & 1 & 0 & 0 & 1 \\
\hline 168 & & Megachile sp.5 & 1 & 0 & 0 & 1 \\
\hline 169 & & Megachile sp. 6 & 0 & 0 & 3 & 3 \\
\hline 170 & & Megachile sp.7 & 0 & 0 & 1 & 1 \\
\hline 171 & & Rhynostelis plesiognatha Parizotto \& Melo & 0 & 0 & 1 & 1 \\
\hline \multicolumn{3}{|c|}{ Total } & 1926 & 91 & 2126 & 4143 \\
\hline
\end{tabular}

\section{DISCUSSION}

As far as we know, this is one of the first great native bee lists using more than one sampling methodology associated with a native crop in an area with a crop and surrounding forest and open secondary vegetation in the Brazilian Amazonia and probably the first broad survey of a local bee fauna in the Amazon region since DUCKE (1906). In spite of differences in the collection periods and epoch for passive and active methods, it is assumed that the results, especially the high number of species recorded exclusively by malaise and by active methods, stress the importance of using different sampling methods to get highest possible diversity. Increasing occurrence records for places where we lack species occurrence and distribution may increase our reliability on conservation studies (HORTAL et al. 2015). 
GonçaLVES \& BRANDÃo (2008) using the same three sampling methods that we use in Atlantic Forest, found out that the most effective technique in capturing bees was the trap Malaise (84 species collected), followed by hand net sampling (39 species) and yellow pan-traps (Moericke) captured only five species. Though Krug \& Alves-Dos-SANTOS (2008) discovered that yellow pan traps were useful in bees sampling in an Araucaria forest (72 species were collected in pantraps and 130 species were sampled with hand net), they did not use Malaise traps. In this work we found a close number of species being collected with Malaise and hand net, while pantraps capture few species when compared to the two previous methodologies.

Table 3. The proportion of common and unique species in each method of sampling expressed in percentage.

\begin{tabular}{lccccc}
\hline & Malaise & Pan-traps & Active & Unique & H' $^{\prime}$ \\
\hline Malaise & 0 & 2.3 & 32.2 & 29.2 & 3.42 \\
Pan-traps & 2.3 & 0 & 0.5 & 1.2 & 1.9 \\
Active & 32.2 & 0.5 & 0 & 30.5 & 3.59 \\
\hline
\end{tabular}

\section{Species accumulation curves}

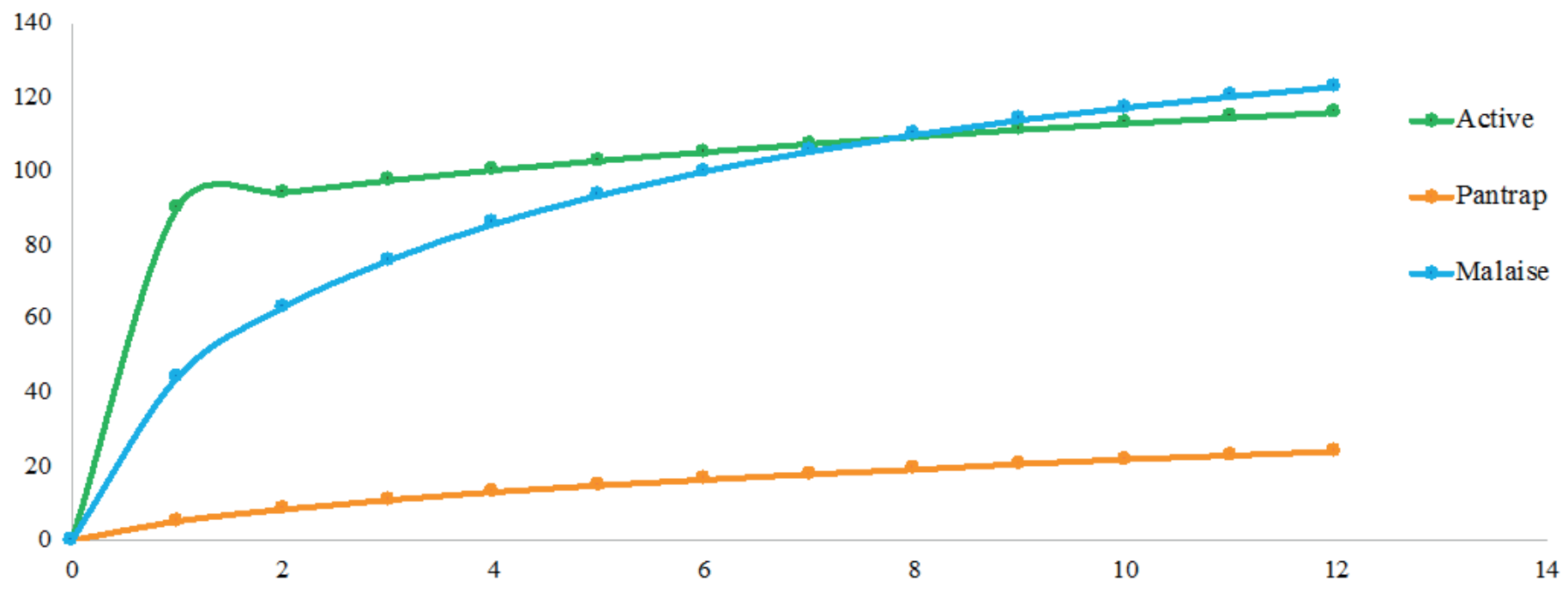

Figure 3. Species accumulation curves for each of the sampled methods used in one guarana crop field and surrounding natural habitat in the Brazilian Amazon.

near a large urban center and for a restricted period. Legal Amazon has an approximate surface area of 5,015,067.75 $\mathrm{km}^{2}$, corresponding to about $58.9 \%$ of the Brazilian territory (IBGE 2021).

Therefore, when we think on the classical biogeographic distribution pattern of bee species on a global scale, the regions with the highest bee diversity are the temperate dry ones (Michener 1979, 2007; Silveira et al. 2002). Even though the same authors pointed out that the bee fauna in the Amazon region remains essentially unknown. Intensive inventories of local bee faunas in the amazon region, especially if representing different regions and landscapes, should contribute to minimize this limitation. Moreover, we sampled 171 bee species and morphospecies, probably some of these not yet described, and a new record for Brazil (Hylaeus orbicus, MahLMANn et al. 2020). The hardship of access to many parts of the Amazon forest, high costs of mobility, and distance from research centers are the main factors that contribute to this lack of knowledge. Borges et al. (2020) recorded a total of 222 species in Carajás, representing nearly $80 \%$ of the bee fauna in Pará State and 33\% of these bees (at least at the generic level) have been identified as crop pollinators. ABsy et al. (2018) made a review of studies previously conducted in the Brazilian Amazon using pollen analyses of 48 stingless bees,
As stated by Michener $(1979,2007)$ that tropics present the lowest diversity when compared to other regions, a scenario also described by OrR et al. (2021), but both studies are limited by the scary knowledge of bee diversity in tropical forests, for example the really limited number of local bees diversity surveys in the Brazilian Amazonia (see above and PINHEIROMACHADO et al. 2002) provide those records can be more complex.

Until now, 773 species of bees are currently recognized for the entire northern region of Brazil (seven states of the Federation: Acre, Amapá, Amazonas, Pará, Rondônia, Roraima, and the Tocantins), which correspond to $43.4 \%$ of the species registered for the country. Considering those numbers, we could say that we sampled approximately $20 \%$ of the species richness known for this region (even considering possible new species or new records among the undetermined species recorded here). This relatively expressive representation becomes even more evident if we take into account that the study was carried out in a small sampling site with the anthropic influence of agriculture and 
BAYO \& WYCKHUYS 2019), there are still numerous regions with an absence of information. These gaps can be also aggravated by the lack of Brazilian policies to protect natural pollinators populations (HIPóLITo et al. 2021). In Brazil, pollinators contribute at least US\$12 billion to total annual agricultural economics (GIANNINI et al. 2015), and due to many anthropic harms to biodiversity especially in the Amazon region (e.g., fires, loss of natural landscapes), we risk losing a lot of our biodiversity before we even know it. Our guarana fields were close to natural areas, probably supporting a higher bee diversity which in turn benefit guarana crops (KLeIN et al. 2007).

We found out that combined surveys with Malaise and hand net contribute to produce a better representativeness of local bee faunas in the Amazon region, as already found for other regions.

We observed a relatively high diversity of wild bees in a local bee fauna adjacent to an agricultural area of guarana, even considering only an annual survey based on hand netting or malaise traps, demonstrate that if more similar collection efforts are undertaken in several sites in this huge region, especially in areas and phytophysiognomies not well studied until now, we probably will have a more realistic view of the Amazon bee diversity.

\section{ACKNOWLEDGMENTS}

We are grateful to Manoel Alvino Santos Andrade for the help with fieldwork and to David Nogueira, for the Scaura and Tetragona identifications. Part of this study was financed in part by the Coordenação de Aperfeiçoamento de Pessoal de Nível Superior - Brasil (CAPES) - Finance Code 0001, scholarship granted to the third and fourth authors. To CNPq productivity grant received by MLO (305150/2020-0). This project received funding from EMBRAPA via Project 02.16.04.024.00.01.000.

\section{REFERENCES}

Absy, ML, AR Rech \& MG Ferreira MG, 2018. Pollen Collected by Stingless Bees: A Contribution to Understanding Amazonian Biodiversity, pp 29-46. In: Vit P, SRM Pedro \& DW Roubik (Eds.). Pot-Pollen in Stingless Bee Melittology. Springer International Publishing. DOI: https://doi.org/10.1007/978-3-319-61839-5_3

Antonio, IC, 2017. Estação Agroclimatológica da Embrapa Amazônia Ocidental na Rodovia AM-010, Km 29-Manaus. Amazônia Ocidental: EMBRAPA (Boletim agrometeorológico, 60).

Ascher, JS \& J Pickering, 2018. Discover Life bee species guide and world checklist (Hymenoptera: Apoidea: Anthophila). Available in: <https://www.discoverlife.org/ mp/20q?guide=Apoidea_species>. [Access: 01.vii.2019].

Bezerra, LA, AJ Campbell, TF Brito, C Menezes \& M Maués, 2020. Pollen Loads of Flower Visitors to Açaí Palm (Euterpe oleracea) and Implications for Management of Pollination Services. Neotropical Entomology, 49: 482-490. DOI: https://doi.org/10.1007/s13744-020-00790-x

Biesmeijer, JC, SPM Roberts, M Reemer, R Ohlemuiller, $M$ Edwards, T Peeters, AP Schaffers, SG Potts, R Kleukers, CD Thomas, J Setteleand \& WE Kunin, 2006. Parallel Declines in Pollinators and Insect-Pollinated Plants in Britain and the Netherlands. Science, 313: 351-354. DOI: https://doi.org/10.1126/science.1127863

Borges, RC, K Padovani, VL Imperatriz-Fonseca \& TC Giannini, 2020. A dataset of multi-functional ecological traits of Brazilian bees. Scientific Data, 7: 120. DOI: https://doi.org/10.1038/s41597-020-0461-3

Campbell, AJ, LG Carvalheiro, MM Maués, R Jaffé, TC Giannini, MAB Freitas, BT Coelho \& C Menezes, 2018. Anthropogenic disturbance of tropical forests threatens pollination services to açaí palm in the Amazon river delta. J-ournal of Applied Ecology, 55: 1725-1736. DOI: https://doi.org/10.1111/1365-2664.13086

Camargo, JMF, 1970. Ninhos e biologia de algumas espécies de Meliponideos (Hymenoptera: Apidae) da região de Pôrto Velho, Território de Rondônia, Brasil. Revista de Biología Tropical, 16: 207-239.

Cardoso, P, F Rigal \& JC Carvalho, 2015. BAT - Biodiversity Assessment Tools, an $\mathrm{R}$ package for the measurement and estimation of alpha and beta taxon, phylogenetic and functional diversity. Methods in Ecology and Evolution, 6: 232-326. DOI: https://doi.org/10.1111/2041-210X.12310

Corlett, RT, RB Primack, V Devictor, B Maas, VR Goswami, AE Bates, LP Koh, TJ Regan, R Loyola, RJ Pakeman, GS Cumming, A Pidgeon, D Johns \& R Roth, 2020. Impacts of the coronavirus pandemic on biodiversity conservation. Biological Conservation, 246: 108571. DOI: https://doi.org/10.1016/j.biocon.2020.108571

Ducke, A, 1906. Neue Beobachtungen über die Bienen der Amazonasländer. Zeitschrift für wissenschaftliche Insektenbiologie, 2: 51-60.

Ellwanger, JH, B Kulmann-Leal, VL Kaminski, JM ValverdeVillegas, ABG da Veiga, FR Spilki, PM Fearnside, L Caesar, LL Giatti, GL Wallau, SEM Almeida, MR Borba, VP da Hora \& JAB Chies, 2020. Beyond diversity loss and climate change: Impacts of Amazon deforestation on infectious diseases and public health. Anais da Academia Brasileira de Ciências, 92: e20191375. DOI: https://doi.org/10.1590/0001-3765202020191375

Escobar, JR, MPF Corrêa \& FP Aguilera, 1984. Estruturas florais, floração e técnicas para a polinização controlada do guaranazeiro. Pesquisa Agropecuária Brasileira, 19: 615-622.

Foley, JA, GP Asner, MH Costa, MT Coe, R de Fries, HK Gibbs, EA Howard, S Olson, J Patz, N Ramankutty \& P Snyder, 2007. Amazonia revealed: forest degradation and loss of ecosystemgoodsandservicesintheAmazonBasin. Frontiers in Ecology and the Environment, 5: 25-32. DOI: https://doi. org/10.1890/1540-9295(2007)5[25:ARFDAL]2.0.CO;2

Giannini, TC, S Boff, GD Cordeiro, EA Cartolano, AK Veiga, VL Imperatriz-Fonseca \& AM Saraiva, 2015. Crop pollinators in Brazil: a review of reported interactions. Apidologie, 46: 209-223. DOI: https://doi.org/10.1007/s13592-014-0316-z

Giannini, TC, WF Costa, RC Borges, C Cabral, L Miranda, CPW Costa, AM Saraiva \& VL Imperatriz-Fonseca, 2020. Climate change in the Eastern Amazon: crop-pollinator and occurrence-restricted bees are potentially more affected. Regional Environmental Change, 20: 9. DOI: https://doi.org/10.1007/s10113-020-01611-y

Gonçalves, RB \& CRF Brandão, 2008. Diversidade de abelhas (Hymenoptera, Apidae) ao longo de um gradiente latitudinal na Mata Atlântica. Biota Neotropica, 8: 51-61. DOI: https://doi.org/10.1590/S1676-06032008000400004

Hammer, Ø, DAT Harper \& PD Ryan, 2001. PAST: Paleontological statistics software package for education and data analysis. Paleontologia eletronica, 4: 9. Available in: <https://palaeo-electronica.org/2001_1/past/past.pdf>

Hipólito, J, J Coutinho, T Mahlmann, TBR Santana \& WE Magnusson, 2021. Legislation and pollination: Recommendations for policymakers and scientists. Perspectives in Ecology and Conservation, 19: 1-9. DOI: https://doi.org/10.1016/j.pecon.2021.01.003

Hortal, J, F de Bello, JAF Diniz-Filho, TM Lewinsohn, JM Lobo \& RJ Ladle, 2015. Seven Shortfalls that Beset LargeScale Knowledge of Biodiversity. Annual Review of Ecology, Evolution and Systematics, 46: 523-549. DOI: https://doi.org/10.1146/annurev-ecolsys-112414-054400

IBGE, 2021. Instituto Brasileiro de Geografia e Estatística. Projeção da população brasileira e das unidades da federação. Available on <http://tabnet.datasus.gov.br/ cgi/deftohtm.exe?ibge/cnv/projpopuf.def>.

[Access: 01.vi.2020] 
Klein, A-M, BE Vaissière, JH Cane, I Steffan-Dewenter, SA Cunningham, C Kremem \& T Tscharnke, 2007. Importance of pollinators in changing landscapes for world crops. Proceedings of the Royal Society B: Biological Sciences, 274: 303-313. DOI: https://doi.org/10.1098/rspb.2006.3721

Köppen, W, 1936. Das geographische system der klimate. Hundbuch der Klimatologie, $1^{\text {st }}$ Ed. Berlin, Gebrüder Borntraeger.

Kress, WJ, WR Heyer, P Acevedo, J. Coddington, D Cole, TL Erwin, BJ Meggers, M Pogue, RW Thorington, R P Vari, MJ Weitzman \& SH Weitzman, 1998. Amazonian biodiversity: assessing conservation priorities with taxonomic data. Biodiversity and Conservation, 7: 1577-1587. DOI: https://doi.org/10.1023/A:1008889803319

Krug, C\&I Alves-dos-Santos, 2008. O uso de diferentes métodos para amostragem da fauna de abelhas (Hymenoptera: Apoidea), um estudo em floresta ombrófila mista em Santa Catarina. Neotropical Entomology, 37: 265-278. DOI: https://doi.org/10.1590/S1519-566X2008000300005

Krug, C, GD Cordeiro, I Schäffler, Cl Silva, R Oliveira, C Schlindwein, S Dötterl \& I Alves-dos-Santos, 2018. Nocturnal Bee Pollinators Are Attracted to Guarana Flowers by Their Scents. Frontier in Plant Science, 9: 1072. DOI: https://doi.org/10.3389/fpls.2018.01072

Krug, C, MVB Garcia \& FB Gomes, 2015. A scientific note on new insights in the pollination of guarana (Paullinia cupana var. sorbilis). Apidologie, 46: 164-166. DOI: https://doi.org/10.1007/s13592-014-0304-3

Lewis, CN \& JB Whitfield, 1999. Braconid Wasp (Hymenoptera: Braconidae) Diversity in Forest Plots Under Different Silvicultural Methods. Environmental Entomology, 28: 986-997. DOI: https://doi.org/10.1093/ee/28.6.986

Mahlmann, T, J Hipólito, M Montefusco \& C Krug, 2020. First record of the neotropical subgenus Hylaeus (Gongyloprosopis) Snelling, 1982, for Brazil (Hymenoptera: Colletidae). Entomological Communications, 2: ec02012. DOI: https://doi.org/10.37486/2675-1305.ec02012

Maués, MM, C Krug, LHO Wadt, PM Drumond, MC Cavalcante \& ACS Santos, 2015. A castanheira-do-brasil: avanços no conhecimento das práticas amigáveis à polinização. 1 Ed. Rio de Janeiro, Fundo Brasileiro para a BiodiversidadeFUNBIO.

Maués, MM, MC Cavalcante, ACS Santos \& C Krug, 2018. Brazil nut in the Amazon, pp. 220-225. In: Roubik, DW. (Ed.). The pollination of cultivated plants: A compendium for practitioners. 1ed. Rome, FAO.

Meiners, JM, TL Griswold \& OM Carril, 2019. Decades of native bee biodiversity surveys at Pinnacles National Park highlight the importance of monitoring natural areas over time. PLOS ONE, 14: e0207566. DOI: https://doi.org/10.1371/journal.pone.0207566

Michener, CD, 1979. Biogeography of the Bees. Annals of the Missouri Botanical Garden, 66: 277. DOI: https://doi.org/10.2307/2398833

Michener, CD, 2007. The bees of the world, 2nd ed. Baltimore, Johns Hopkins University Press.

Morato, EF, MVB Garcia \& LA de O Campos, 1999. Biologia de Centris Fabricius (Hymenoptera, Anthophoridae, Centridini) em matas contínuas e fragmentos na Amazônia Central. Revista Brasileira de Zoologia, 16: 1213-1222. DOI: https://doi.org/10.1590/S0101-81751999000400029

Oliveira, ML de, 1999. Sazonalidade e horário de atividade de abelhas Euglossinae (Hymenoptera, Apidae), em florestas de terra firme na Amazônia Central. Revista Brasileira de Zoologia, 16: 83-90. DOI: https://doi.org/10.1590/S010181751999000100003

Oliveira, ML de \& LA de O Campos, 1995. Abundância, riqueza e diversidade de abelhas Euglossinae (Hymenoptera, Apidae) em florestas contínuas de terra firme na Amazônia Central, Brasil. Revista Brasileira de Zoologia, 12: 547-556. DOI: https://doi.org/10.1590/S0101-81751995000300009
Oliveira, ML, EF Morato \& MVB Garcia, 1995. Diversidade de espécies e densidade de ninhos de abelhas sociais sem ferrão (Hymenoptera, Apidae, Meliponinae) em floresta de terra firme na Amazônia central. Revista Brasileira de Zoologia, 12: 13-24. DOI: https://doi.org/10.1590/S010181751995000100004

Oliveira, ML de, 2015. Andrenidae, Apidae, Colletidae, Halictidae, Megachilidae In Catálogo Taxonômico da Fauna do Brasil. PNUD. Available in: <http://fauna.jbrj.gov. br/fauna/faunadobrasil/1295>. [Access: 14.ix.2019].

Oliveira, MM, CI Silva, FB Gomes, MM Maués, ML de Oliveira \& C Krug, 2020. Bees, plants and pollen in Central Amazonia how surrounding areas contribute to pollination of guarana (Paullinia cupana var. sorbilis (Mart.) Ducke), pp. 50-59. In: Silva Cl, JN Radaeski, MVN Arena \& SG Bauermann (Eds.). Atlas of pollen and plants used by bees. 1ed. Rio Claro, CISE.

Orr, MC, AC Hughes, D Chesters, J Pickering, CD Zhu \& JS Ascher, 2021. Global Patterns and Drivers of Bee Distribution. Current Biology, 31: 451-458. DOI: https://doi.org/10.1016/j.cub.2020.10.053

Pinheiro-Machado, C, I Alves-dos-Santos, VL ImperatrizFonseca, ADMP Kleinert \& FA Silveira, 2002. Brazilian bee surveys: state of knowledge, conservation and sustainable use, p.115-129. In: Kevan P \& VL Imperatriz Fonseca (Eds.). Pollinating Bees, The Conservation Link Between Agriculture and Nature. Brasília, Ministério do Meio Ambiente.

R Development Core Team, 2019. R: A language and environment for statistical computing. $\mathrm{R}$ Foundation for Statistical Computing. Available in: $<$ https://www.R-project. org>.

Rondeau, D, B Perry \& F Grimard, 2020. The Consequences of COVID-19 and Other Disasters for Wildlife and Biodiversity. Environmental and Resource Economics, 76: 945-961. DOI: https://doi.org/10.1007/s10640-020-00480-7

Sánchez-Bayo, F \& KAG Wyckhuys, 2019. Worldwide decline of the entomofauna: A review of its drivers. Biological Conservation, 232: 8-27. DOI: https://doi.org/10.1016/j. biocon.2019.01.020

Schoeninger, K, JLP Souza, C Krug \& ML de Oliveira, 2019. Diversity of parasitoid wasps in conventional and organic guarana (Paullinia cupana var. sorbilis) cultivation areas in the Brazilian Amazon. Acta Amazonica, 49: 283-293. DOI: https://doi.org/10.1590/1809-4392201804560

Silveira, FA, GAR Melo \& EAB Almeida, 2002. Abelhas brasileiras: sistemática e identificação, 1 Ed. Belo Horizonte, FA Silveira.

Schultz, QS \& ACC Valois, 1974. Estudos sobre o mecanismo de floração e frutificação do guaranazeiro. IPAAO (Boletim Técnico 4: 35-36).

Tavares, AM, AL Atroch, FJ Nascimento-Filho, JCR Pereira, JCA Araújo \& LAC Moraes, 2005. Cultura do guaranazeiro no Amazonas 4 Ed., pp. 1-40. In: Pereira, JCR (Ed.). Embrapa Amazônia Ocidental - Sistemas de Produção 2. Manaus, Embrapa.

Townes, H., 1972. A light-weight Malaise trap. Entomological News, 83: 239-247.

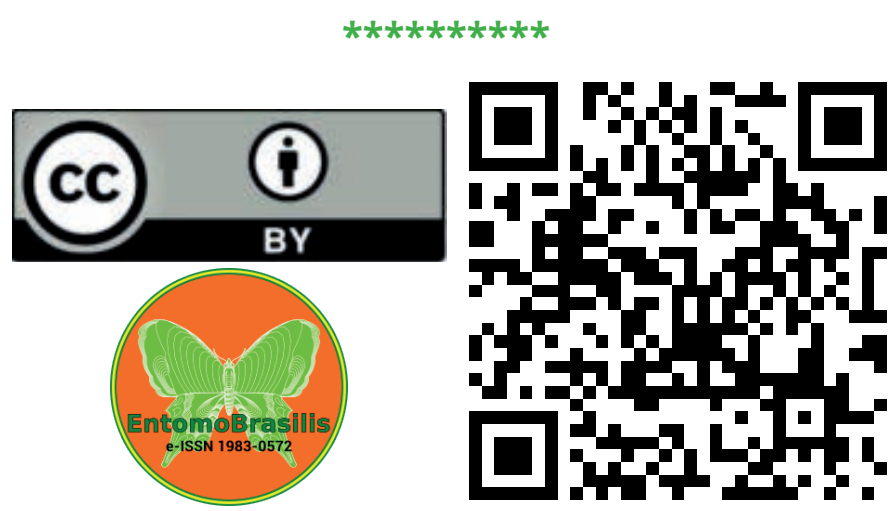

